\title{
THE RECEPTION HISTORY OF THE DUTCH STATENBIJBEL IN HUNGARY IN THE 17TH CENTURY
}

\author{
Péter Eredics
}

\begin{abstract}
In the middle of the 16th century, the Reformation gained ground in Hungary, and would-be Protestant ministers sought theological education in Western Europe, as there was no Calvinist university in their homeland. Unfortunately, translations from Dutch to Hungarian in the Early Modern Period have not received the attention they deserve, given their undoubted importance. This article summarises a project for researching the exegetical coomentaries of István Szathmári Ötvös (d. 1655), whose Titkok jelenese, Avagy, Sz. Janos Apostol Mennyei-Latasa. Roevid magyarázo jedzésekkel edgyuett (Secret Signs, or Visions of St John the Apostle) was published posthumously in 1668 in Szeben (now Sibiu in Romania). The author examines the part that Ötvös and his work played in the cultural relations between Hungary and the Republic of the United Provinces in the 17th century. By working out which source underlies the book, and comparing the texts of the original and the Hungarian version, we will hopefully understand which translation method(s), philological precision, and freedom in revision were employed by Szathmári Ötvös.
\end{abstract}

In the middle of the 16th century, the Reformation won ground in Hungary. The Hungarian would-be ministers on whose shoulders the greater part of the evangelisation rested were forced to seek their theological education in Western Europe, as there was no Calvinistic university in their homeland. ${ }^{1}$ The peregrinatio hungarica in the German direction reached an unprecedented culmination in the century of the Reformation. Wittenberg was particularly popular, but from the 1560s onwards the importance of cities such as Frankfurt and der Oder and Heidelberg gradually increased.

The outbreak of the Thirty Years' War (1618-1648) meant a turning point. During this time, studying in Germany was not without risk, and due to the hostilities it was often even impossible.

${ }^{1}$ I. Bitskey, 'Konfessionen und literarische Gattungen der frühen Neuzeit in Ungarn', Debrecener Studien zur Literatur 4 (Frankfurt am Main, 1999), pp. 15-38. 
Switzerland continued to be popular with the Hungarians, but they also spotted the Republic of the United Provinces, especially after the destruction of Heidelberg in September 1622. The small country on the North Sea with its institutes was no longer unknown to the Hungarians, since the book Europica varietas by Márton Szepsi Csombor (1595-1622) was published in 1622 in Kassa (now Košice in Slovakia), in which the author describes the provinces of Friesland, Holland and Zeeland and their most important cities. ${ }^{2}$ Also the fact that the universities and the athenaea illustria in the Netherlands were important representatives of the Calvinist school of thought made the choice of students from Hungary, who shared the same faith or confession, easier. Moreover, the scholarships and other privileges that were offered are not a negligible factor. Students were continuously in the Netherlands until the end of the 18th century. This special period marked an unequalled peak in the cultural relationship between the two countries.

The Hungarians not only took the acquired knowledge back to their homeland. In their luggage, they enclosed many books, often from Dutch printers. Even the first Hungarian encyclopedia, the Magyar encyclopaedia by János Apáczai Csere (1625-1659), was printed in Utrecht. ${ }^{3}$ These kinds of books not only strengthened the scientific and religious potency in Hungary, they also stimulated the use of the mother tongue in the fields of education and science. A major part of these books were translations into Hungarian. The students were very diligent in this sphere. Contemporary sources show that most of them had a perfect command of Latin, as well as other languages too. ${ }^{4}$ It will not come as a surprise that in Hungarian libraries with early prints, translations from German, English and Latin are well represented. The above-named sources also mention the thorough knowledge of Dutch by students. Having in mind the number of Hungarians in the Republic, the popularity of the language of the host country will not come as a surprise. Many of them found welcome lodgings with Dutch families during

${ }^{2}$ Régi Magyarországi Nyomtatványok (hereafter - RMNy), ed. G. Borsa, vols. 1-3 (Budapest, 1971-2000), 1219.

${ }^{3} R M N y, 2617$.

${ }^{4}$ P. Eredics, Ungarische Studenten und ihre Übersetzungen aus dem Niederländischen ins Ungarische in der Frühen Neuzeit [Debrecener Studien zur Literatur 14] (Frankfurt am Main 2008), pp. 11-12. 
their stay. If they wanted to communicate with the family, who very often did not have a good command of Latin, it was inevitable for them to learn Dutch. In a letter from 1657 from a former student to his son, we can read the following advice: 'It's important, my dear son, that you start learning Dutch shortly after your arrival, and that you practise for a while every day after dinner. Otherwise, you will find that it is sorrowful to be in a country of which the language one does not speak. ${ }^{5}$ The question is, were there many among them who not only used the language for conversations with the landlady, but also to translate books into Hungarian?

Considering the well-documented reception of Dutch books in Germany in the named period, the answer to the above question seems obvious. ${ }^{6}$ Nevertheless, documentation of translations into Hungarian can be considered a neglected field of research. At the end of the 1990s a start was made to fill this gap. Historical and bibliographical research into printed and handwritten catalogues, national bibliographies, translations and sources in libraries and archives in a number of European countries, like Germany, Hungary, the Netherlands, Romania and Slovakia, was commenced. About ten translations from the 17th and 18th centuries were found. Concerning content, they can be divided into three categories: devotional works; catechism editions; exegetical works.

István Szathmári Ötvös (?-1665) and his Titkok jelenese When my dissertation Ungarische Studenten und Ihre Übersetzungen aus dem Niederländischen in der Frühen Neuzeit, in which I take a closer look at three of the four Hungarian translations, was published in 2008 , the first part of the project was finished. The above-mentioned sequel will be completely devoted to the exegetical commentaries of the former student István Szathmári Ötvös (?-1655), whose Titkok jelenese, Avagy, Sz. Janos Apostol Mennyei-Latasa. Roevid magyarázo jedzésekkel edgyuett (further Titkok jelenese) was posthumously published in 1668 in Szeben (now Sibiu in Romania). ${ }^{7}$

Next to nothing is known about the descent of Szathmári Ötvös. It is certain that he studied at the Calvinist college in Sárospatak,

${ }^{5}$ Ibid.

${ }^{6} \mathrm{http}: / / w w w . i n d u . n i e d e r l a n d i s t i k . f u-b e r l i n . d e$

${ }^{7}$ Régi Magyar Könyvtár (RMK), ed. K. Szabó, Á. Hellebrant, vol. 1 (Budapest 1879-1898), p. 1078. 
where he signed the Academic Statutes of the college on 10 December 1643. In order to secure financial means for his foreign study tour, he accepted an appointment as a teacher in the nearby village of Bodrogkeresztúr. Szathmári Ötvös departed for the Netherlands as an alumnus of Zsuzsanna Lorántffy (1600-1660), the widow of the Transylvanian sovereign György (Georgius) Rákóczi I (1593-1648), and of her son Zsigmond (Sigismundus) Rákóczi (1622-1652). He enrolled as a student of theology on 18 July 1649 at the University of Franeker. After a short stay in Friesland, he lived in Utrecht from 1650 onwards. ${ }^{8}$ In the cathedral city, Szathmári Ötvös energetically took part in the disputes, which in the 17 th century were, besides the formal lectures (lectiones), one of the main academic teaching methods. Presided over by the professor, the students - or respondentes - defended a number of propositions. The printed disputations, which before going to press were completely reviewed and corrected by the presiding professor, were used as topics for reflection in public and private disputes. Szathmári Ötvös made his first appearance in a public dispute that was led by Johannes Hoornbeeck (1617-1666) on 9 March 1650. The title of his disputation was De studio verbi divini. ${ }^{9}$ A year later, he appeared in a sequence of three disputations that were held between 22 March and 10 May. ${ }^{10}$ The first and second parts of De sepultura mortuorum were led by Carolus de Maets (1597-1651). After his death on 20 April, his friend and colleague Gisbertus Voetius (1598-1678) presided over the third round. ${ }^{11}$

The disputations, which at the time did not always get the recognition they would have deserved as academic printing, are now a mine of information for the researcher. ${ }^{12}$ From them, it is deducible when and under which professor the respondents in question studied. The verso of the title page was usually allocated for dedications. From this, we can deduce who the patrons and patronesses were.

${ }^{8}$ Magyarországi diákok holland egyetemeken, 1595-1918 // Hongaarse studenten aan Nederlandse universiteiten, 1595-1918, ed. R. Bozzay, S. Ladányi (Budapest 2007), No. 277 and 1293.

${ }^{9} R M K$, vol. III, 1760.

${ }^{10} R M K$, vol. III, 1790 .

${ }^{11}$ Ibid.

12 Despite the Senate's decision, the Leiden librarian and professor Daniël Heinsius (1580-1655) decided against the collection and binding of the disputations that had already been published previously. Cf. S. van der Woude, 'De oude Nederlandse dissertaties', Bibliotheekleven, 48 (1963), p. 3. 
The panegyrics at the end, written by friends in different languages, reveal a lot about the connections of the student. Likewise with Szathmári Ötvös, by whom a verse in Hebrew was included in an exercise disputation of his fellow countryman György Komáromi Csipkes (1628-1678), who later became a famous theologian and professor. This small detail gives us an insight into his circle of friends. ${ }^{13}$

An interesting book with two Hungarian works that was published in 1650 by Johannes Janssonius (1596-1664) in Amsterdam shows us that this group of students did more than just disputing. ${ }^{14}$ The first part of the book contains A KERESZTYÉNI vallásra rövid kérdésekben es feleletekben tanito catechesis. From the introduction, we can determine that it is a version of the Heidelberg Catechismus that was written in Latin by professors of Leiden University. What the source is, is still a mystery. Neither are the names of the translators revealed, but the Hungarian Church historian Barna Nagy alleges that, amongst others, Szathmári Ötvös and Komáromi Csipkés were involved in the translation. ${ }^{15}$ Szathmári Ötvös certainly translated the second part, Az keresztyén es igaztudományu belgiomi ecclesiáknak hitekröl valo vallás tétele that has its origins in the Confession de foy, the Dutch confession of faith that was written in French by the Walloon minister Guy de Brès (1522-1567) and that was later adapted by Jacobus Revius (1586-1658). From 1623 onwards, it was frequently published. ${ }^{16}$

It is unclear when Szathmári Ötvös returned to Hungary. From 1654 until 1656, he worked as a professor in his alma mater in Sárospatak. The assumption is that, by translating a number of Dutch extracts, he played a major role in the realisation of the publication of the catechism Catechismus (Keresztyen) Az az: A' keresztyeni Hitnek ágazataira való roevid tanitás, kérdések és feleletek által (Sárospatak 1656). ${ }^{17}$ From 1656 onwards, Szathmári Ötvös was a

${ }^{13} R M K$, vol. III, 1780 .

${ }^{14} R M N y, 2304$.

${ }^{15}$ B. Nagy, 'A Heidelbergi Káté jelentkezése, története és kiadásai Magyarországon a XVI. és XVII. században', A Heidelbergi Káté története Magyarországon (Studia et Acta Ecclesiastica 1), ed. T. Bartha, (Budapest 1965), pp. 55-6.

${ }^{16}$ Short-Title Catalogue Netherlands (http://www.kb.nl/stcn/)

${ }^{17}$ Nagy, 'A Heidelbergi Káté jelentkezése', pp. 63-4. 
minister in Érsekújvár in the northern part of Hungary (nowadays Nové Zámky in Slovakia). In 1663, after the capture of the city by the Turks, he fled to the village of Kocs where he worked until his death in 1665 .

In 1668, his exegesis Titkok jelenese appeared posthumously in an octavo edition in the printing office of Mihály Udvarhelyi in Szeben. The designation on the title page 'the newly translated and extended with explanatory remarks Dutch Bible' made it easy to trace the source. The Synod of Dordrecht (1618-1619) had given a number of prominent theologians the assignment for a new, accurate Bible translation directly from the original text. Their effort resulted in the Statenbijbel, or Statenvertaling, which was published for the first time in Leiden in 1637, and which has been reprinted countless times since then. To improve the readability and the understanding of Scripture, all books of the Old and New Testament were supplemented with annotations in the margin. The Song of Songs and the not easily accessible Book of Revelation were exhaustively annotated. Nevertheless, Szathmári did not shy away from translating this book into Hungarian. In his composition, he follows on the Dutch source book. He first translates the short summary of Revelations (Inhoudt deses Boecks) and subsequently the annotations.

There are still a lot of questions concerning the time and the place when Szathmári Ötvös put his writing on paper, only after his return to Hungary or still during his stay in the Netherlands. Thanks to the dedication of the originator of this publication, János Debreceni Kalocsa (1632-1710) in Titkok jelenese, we have a good insight into the history of the development of this book until 2 June 1666. A transcript, not the original, of Szathmári Ötvös' manuscript was found by a bookseller in the city of Nagykörös, and he handed it over as a valuable text to the minister Debreceni Kalocsa. Debreceni Kalocsa liked the book to such an extent that he wanted to publish it. He was experienced in this sphere, as he had guided the publication of another book by a former student in 1662 . The accomplishment of the financing of Titkok jelenese was not achieved just like that. In the dedication, he complained about the stinginess and the shortsightedness of his fellow countrymen 'because some folks can only think about the here and now, and have never heard 
about an immortal experience'. ${ }^{18}$ Eventually, the same financier as before, the wealthy citizen Ambrus Kamarás from Kecskemét, coughed up the money. He had helped him out in 1662 too.

After the last translated annotation in Titkok jelenese, the following sentence can be found: 'Anno Dni 1668 Die 17. Febr. Absolutum hoc opus per me Gasp. Gatsaly in Oppido Thornensi.' ${ }^{19}$ There is unfortunately at this time no satisfying answer yet to the question why it took so long: the book was made ready for the press more than a year and a half after Debreceni Kalocsa had dated his dedication on 2 June 1666. The death of the printer in Szeben, Ábrahám Szenci Kertész, in 1667, and the appointment of his successor Mihály Udvarhelyi probably played a part. Thus, the book was finally released to the public in 1668 after a lot of delay. After consulting the old catalogues and reading lists, it turns out that at the time it was a popular publication. Therefore, it is surprising that it was never reprinted. It is beyond dispute that the Statenbijbel had a great influence, even beyond the Dutch borders. ${ }^{20}$ Even the annotations were published separately in several languages. The best example is presumably the English integral translation by the German Theodorus Haak (1605-1690), who received this assignment from the English Parliament. However, in the Hungarian region the undertaking of Szathmári Ötvös was unique.

Research questions The primary research question concerns the part the translator Szathmári Ötvös and his work Titkok jelenese played in cultural relations between Hungary and the Republic of the United Provinces in the 17th century. By working out which source underlies the book of Szathmári Ötvös, the first step in the right direction was taken. A comparison of the texts will hopefully show which translation method(s), philological precision, freedom in revision, denotations-orientated method etc. were employed by Szathmári Ötvös. A textual analysis should show if there are diffe-

${ }^{18}$ István Szathmári Ötvös, Titkok jelenese, Avagy, Sz. Janos Apostol MennyeiLatasa. Roevid magyarázo jedzésekkel edgyuett. Mellyek, a’ Belgiomi ujjonnan forditatott, és roevid Magyarázatokkal meg-boevittetett Bibliábol,Magyar nyelven szedegettettek (Szeben, 1668), Ajanlo level, fol. SSr. '[...] mivel hogy némellyek, csak e' világhoz ragaszkodnak, és nem tudgyák mi légyen a halhatatlan emlekezet'.

${ }^{19}$ Ibid., fol. U4v.

${ }^{20}$ A.W.G. Jaakke, 'Ver over de grenzen I. De invloed van de Statenvertaling in het buitenland', Met andere woorden: kwartaalblad over bijbelwerk, 14:1 (1995), pp. 1-6, and (1996) 15-23. 
rences compared to the source, and if there are, what the underlying motives were, and why he made these choices.

Special attention will be given to the financing of the project. What were the underlying motives of the rich benefactor from Kecskemét? Why was the publisher from Szeben interested in the publication of specifically this text by Szathmári Ötvös? In this respect, a description of the publisher's catalogue of the publisher in question is of importance, in order to be able to answer the next questions. Did the Hungarian translation fit in with the books he usually published, or is this translation an exception? With the help of a preserved publishers list, auction catalogues, book lists and the bibliographical and professional literature about the edition, the price and the distribution, we can imagine how popular the translation in Hungary and its Dutch source were.

In my research, I hope to obtain more information about the translation. Besides that, I hope to get more insight into the translator, his motives and his background. At the same time, I hope to find out, if this is still possible after three centuries, if he shared the spirit of his times, and in what way it influenced his decisions. The fact that the book of Szathmári Ötvös, just as all the other found translations from Dutch into Hungarian from the Early Modern Period, has a theological character, puts forward the following questions: on the one hand, which theological movement he preferred, and on the other hand, at what time and place he became acquainted with it. When he was still in Hungary, or during his studies in the Netherlands? If the latter is the case, we should also pay attention to the influence of universities, professors and fellow students. I will work out the above-mentioned questions in four chapters devoted to the life and work of István Szathmári Ötvös; the history of the development of Titkokjelenese; the structural differences, and differences concerning the content, between the translation and its source; and the reception and influence of the translation in Hungary.

The state of research in Hungary and the Netherlands Thanks to the efforts of many people, a lot more attention is nowadays paid to the relationship between Hungary and the Netherlands in the Early Modern Period. Every year, new articles and books on this issue are published. Much attention is given to the study of the students and their backgrounds. ${ }^{21}$ Given their significance in the spread of the Dutch cultural heritage, this is much needed. Even according to

${ }^{21}$ Regarding this, I refer to the publications of, among others, Béla Baráth, Réka Bozzay, Sándor Ladányi and Ferenc Postma. 
the most conservative estimates, the Hungarian student population at Dutch universities and athenae illustria added up to around two thousand people. Therefore, it is not surprising that little is still known about them. Unfortunately, István Szathmári Ötvös is not an exception to the rule. In past decades, hardly any new information has turned up. It is true that we have elementary knowledge about his life, but as it concerns a translator of this exceptional stature, the expectation is that a lot more material can be found in national and international archives and libraries.

What is written in professional Hungarian literature about Szathmári Ötvös' Titkok jelenese? When locating the translations, bibliographical works are important. With regard to the work of Szathmári Ötvös, we can refer to two titles in Hungary: the Hungarian retrospective national bibliography Régi Magyar Könyvtár. It was published at the end of the 19th century, and contains all the early printed works until 1711. It gives a detailed outline, but sadly enough, after its appearance the two world wars left their traces in the region, and a lot of early prints went missing. All these regrettable losses have been incorporated into Régi Magyarországi Nyomtatványok. This modern version of Régi Magyar Könyvtár fulfils all the expectations of the present day. The fourth volume, which contains all the books from the period 1656-1670, thus also a description of Szathmári Ötvös' translation, will be published in the coming months. The editors have been so kind as to give me the opportunity to look into the manuscript, for which I am greatly indebted to their kindness. On the website of the Hungarian National Library (OSzK), the electronic version of both titles can be consulted. ${ }^{22}$

Regrettably enough, an article that is completely dedicated to Titkok jelenese has never been published, and there are only a few commentaries on the content of this book. Noémi Viskolcz quotes Szathmári Ötvös in her research on Millennialism in 17th-century Calvinist literature. 23 Hajnalka Görög derived a few examples from the translation that refer to the Calvinist picturarial tradition. ${ }^{24}$ Other than these, there are no articles on the translation of Szathmári Ötvös in Hungarian professional literature. However, there are articles

$22 \mathrm{http}: / /$ www.arcanum.hu/oszk/

${ }^{23} \mathrm{~N}$. Viskolcz, 'Jövendölések és váradalmak 17. századi protestáns irodalmunkban', A harmincéves háború prófétái és chiliasztái, [Fiatal filológusok füzetei. Korai újkor 4], ed. L. Juhász-Noémi Viskolcz (Szeged 2003), p. 85.

${ }^{24}$ H. Görög, 'Képmetamorfózisok. Protestáns képteológia és alkalmazásai a 17-18. század prédikációelméletében és -gyakorlatában', Erdélyi Múzeum, 63:3-4 (2001), pp. 115-43. 
on Hungarian translations in the Early Modern Period that are of great importance for my research. One of them, written by István Bartók, is a monograph about seven decades of literary tradition in Hungary, between 1630 and $1700 .{ }^{25}$ Bartók devotes part of his book to current stylistic questions and translation studies. He also pays attention to contemporary visions on translating methods, originality, and the benefit and the necessity of translating. An article by the same author entitled $A$ casa rustica és a mechanici is devoted to the stylistic issue, but also deals with other theological texts. ${ }^{26}$ Although none of the above examples are translations from Dutch, their conclusions have proved their advantage for the analysis of Szathmári Ötvös' Titkok jelenese.

The Hungarian version of the annotations on the Book of Revelation have, until this day, passed by unnoticed in the Netherlands, but fortunately a lot of good material about its source is at our disposal. The different editions of the Statenbijbel can be found in the retrospective national bibliography Short-Title Catalogue Netherlands (STCN) that describes editions between 1540 and 1800. The STCN is of great significance. Thanks to the project 'Digitalising Scriptural Passages' of the Dutch Institute for Lexicology, the first edition of the Statenbijbel from 1637 is available for everybody on the internet. At this time, people are working hard on the digitalisation of the standardised text from 1657. The scope of this article is too limited for an exhaustive overview of all the articles that have been published about this significant book. For further reading on the subject of the annotations, I would advise skimming through Aantekeningen bij Kanttekeningen by Cornelis A. Tukker. ${ }^{27}$ Finally, there is the Vertaalhistorie series by Theo Hermans, Luc Korpel and Cornelis W. Schoneveld, that deals with translational views in the Netherlands in the Early Modern Period, a useful resource. ${ }^{28}$

${ }^{25}$ I. Bartók, 'Sokkal magyarabbúl szólhatnánk és írhatnánk', Irodalmi gondolkodás Magyarországon 1630-1700 között (Budapest, 1998), pp. 283-324.

${ }^{26}$ I. Bartók, 'A casa rustica és a mechanici. Az „alacsony stílus“ ismérvei a XVII. század magyar irodalomelméletében', Irodalomtörténeti Közlemények, 96:5-6 (1992), pp. 569-78.

${ }^{27}$ C.A. Tukker, Aantekeningen bij kanttekeningen (Utrecht, 1997), pp. 7-10.

${ }^{28}$ C.W. Schoneveld, 't Word grooter plas, maar niet zoo 't was. Nederlandse beschouwingen over vertalen (1670-1760) [Vertaalhistorie 3] (Gravenhage, 1992); L. Korpel, In Nederduitsch gewaad. Nederlandse beschouwingen over vertalen (1760-1820) [Vertaalhistorie 4] (Gravenhage, 1993); T. Hermans, Door eenen engen hals. Nederlandse beschouwingen over vertalen (1550-1670) [Vertaalhistorie 2] (Gravenhage, 1996). 
From the above we may conclude that unfortunately translations from Dutch to Hungarian in the Early Modern Period have not received the attention they would have been, given their importance, entitled to. After centuries of neglect the study of Szathmári Ötvös' Titkok jelenese deserves thorough research that should reveal why this concealed manuscript stirred the curiosity of the publisher years after the death of its translator, and moreover found him willing to invest money and time in the publication. Whatever motivated him, he has my respect.

\title{
Author Details
}

Péter Eredics took his doctorate at Lajos Kossuth University, Debrecen, in 2006. His monograph based on his dissertation, Ungarische Studenten und ihre Übersetzungen aus dem Niederländischen ins Ungarische in der Frühen Neuzeit, was published by Peter Lang (Frankfurt amMain-Berlin-Brussels, etc) in 2008. His main area of research covers cultural relations between Hungary and the Netherlands in the Early Modern Period. He teaches German at Oranje Nassau College (Zoetermeer)

\section{OLANDŲ ŠVENTOJO RAŠTO VERTIMO STATENBIJBEL ITAKA XVII A. VENGRIJOJE}

Santrauka

\author{
PÉTER EREDICS
}

XVI a. viduryje Reformacijai ịsišaknijus Vengrijoje, būsimieji protestantų dvasininkai ieškojo tinkamo teologinio išsilavinimo Vakaru Europoje, nes jų tėvynejje nebūta jokių reformatų evangelikų universitetų. Deja, ligšiol vertimų iš olandų $\mathfrak{i}$ vengrų kalbą svarba ankstyvaisiais naujaisiais amžiais nepakankamai ištirta. Autorius atkreipia dėmesi i 1655 m. mirusio Istváno Szathmári Ötvöso 1668 m. Sibiuje (Rumunija) išleistus komentarus šv. Apaštalo Jono Apokalipsei (Titkok jelenese, Avagy, Sz. Janos Apostol Mennyei-Latasa. Roevid magyarázo jedzésekkel edgyuett, (Paslèpti ženklai, arba Šv. Apaštalo Jono Regejimai)). Autorius siekia atskleisti šio veikalo vaidmenį kultūros santykiuose tarp Vengrijos ir Olandijos, tirdamas originalo teksto bei vertimo variantus, tuo būdu suprasdamas Otvoso vertimo metodiką, jo filologinių igūdžių tikslumą, interpretavimo laisvę ir t. t. 